\title{
Oncolytic Effect of Adenoviruses Serotypes 5 and 6 Against U87 Glioblastoma Cancer Stem Cells
}

\author{
MARGARITA V. ROMANENKO ${ }^{1 *}$, EVGENIYA V. DOLGOVA ${ }^{2 *}$, IVAN D. OSIPOV ${ }^{1}$, \\ GENRIKH S. RITTER ${ }^{1,2}$, MARIYA S. SIZOVA ${ }^{1}$, ANASTASIA S. PROSKURINA ${ }^{2}$, \\ YAROSLAV R. EFREMOV ${ }^{1,2}$, SERGEY I. BAYBORODIN ${ }^{2}$, EKATERINA A. POTTER ${ }^{2}$, OLEG S. TARANOV ${ }^{3}$, \\ VLADIMIR V. OMIGOV ${ }^{3}$, GALINA V. KOCHNEVA ${ }^{3}$, ANTONINA A. GRAZHDANTSEVA ${ }^{3}$, \\ EVGENIY L. ZAVYALOV ${ }^{2}$, IVAN A. RAZUMOV ${ }^{2}$, SERGEY V. NETESOV ${ }^{1}$ and SERGEY S. BOGACHEV ${ }^{2}$ \\ ${ }^{I}$ Novosibirsk State University, Novosibirsk, Russia; \\ ${ }^{2}$ Institute of Cytology and Genetics, Siberian Branch of Russian Academy of Sciences, Novosibirsk, Russia; \\ ${ }^{3}$ State Research Center of Virology and Biotechnology "Vector", Koltsovo, Novosibirsk, Russia
}

\begin{abstract}
Background/Aim: Oncolytic adenoviruses are promising therapeutic agents against both the bulk of tumor cells and cancer stem cells. The present study intended to test the oncolytic capability of adenovirus serotype 6 (Ad6), which has a lower seroprevalence and hepatotoxicity relatively to adenovirus 5 (Ad5), against the glioblastoma and its cancer stem cells. Materials and Methods: Oncolytic efficacy of Ad6 was compared to widespread Ad5 both in vitro and in vivo, using the U87 and U251 human glioblastoma cell lines and subcutaneously transplanted U87 cells in SCID mice, respectively. Results: Ad6 had a dose-dependent cytotoxicity toward glioblastoma cells in vitro and its intratumoral injections lead to a significant $(p<0.05)$ decrease in volume of U87 xenografts, similarly to Ad5. Based on the innate capability of glioblastoma cancer stem cells to internalize a fluorescent-labeled double-stranded DNA probe, the spatial localization of these cells was estimated and it was shown that the number of cancer stem cells tended to decrease under adenovirus therapy as compared to the control group. Conclusion: Ad6 was shown to be a promising agent for treating glioblastomas.
\end{abstract}

\footnotetext{
*These Authors contributed equally to this work.

Correspondence to: Sergey S. Bogachev, Institute of Cytology and Genetics, Siberian Branch of Russian Academy of Sciences, 10 Lavrentyev ave, Novosibirsk 630090, Russia. Tel: +7 3833634963 , Fax: +7 3833331278, e-mail: labmolbiol@mail.ru ORCID https://orcid.org/0000-0002-2019-9382
}

Key Words: Adenovirus, cancer stem cells, DNA internalization, TAMRA, U87 cell line.
Despite the relatively low occurrence, central nervous system malignancies yield extremely high risks of lethal outcomes. Glioblastoma (GB; grade IV tumor according to the WHO classification) is the most frequent and poorly curable type of brain tumors (1). In contrast to other types of solid tumors, GB extensively invades the surrounding tissues while it rarely metastasizes to other organs (2).

Currently, the medical treatment of GBs involves the maximal surgical resection of the tumor followed by radio and/or chemotherapy. Despite the progress in neurosurgery, the invention of new promising chemotherapeutic agents (for example, temozolomide), the active development of immunotherapy methods as well as the methods of molecular diagnostics, the survival rate of patients with GB has not significantly improved. Thus, 2-, 3-, 4-, and 5-year survival rates are $27.2 \%, 16.0 \%, 12.1 \%$, and $9.8 \%$, respectively (3).

Numerous reports indicate that GBs and other primary brain tumors contain a sub-population of self-renewing tumorigenic cells, commonly referred to as cancer stem cells (CSCs). Glioma CSCs evince a number of features similar to those of neural stem cells, namely capabilities of self-renewal over the course of generations, formation of neurospheres and differentiation, as well as of high motility and formation of the suitable microenvironment (4). In addition, these cells actively express the vascular endothelial growth factor (VEGF), have a high proliferative activity, drug resistance, and resistance to radio and chemotherapy $(2,5-8)$. It is commonly accepted that the failure of existing therapeutic approaches in eliminating CSCs is the key factor in tumor recurrence (9). Thus, the most actual objective in GB elimination is to develop approaches aimed not only at destroying the "committed" tumor bulk, but, in particular, at eliminating CSCs themselves.

Among the most promising agents capable of killing CSCs are oncolytic viruses. The most widely used as an oncolytic agent is adenovirus type 5 (Ad5), for which a high oncolytic 
potential toward GB cells has been numerously shown (10-13). Clinical tests revealed their capability of passing through the blood-brain barrier with subsequent detection in the brain (14). All these facts imply adenoviruses (Ads) as promising oncolytics in GB treatment. The most potent Ad5 recombinant that has passed the first phase in several clinical trials is DNX2401 (Ad5 Delta-24-RGD; tasadenoturev, with a 24-base pair deletion in the E1A gene and RGD-motif in the fiber H-loop). One of these trials demonstrated that DNX-2401 replicates and spreads throughout the tumor volume, as well as induces the infiltration of $\mathrm{CD}^{+}$and $\mathrm{T}^{-}$bet $^{+}$cells. For 5 out of 25 patients, post-treatment survival period exceeded 3 years; in 3 of them, tumor reduced by $\geq 95 \%$ giving a 3 -year relapse-free survival (12). It was also demonstrated that being used in combination with temozolomide, DNX-2401 is well-tolerated and can be safely used demonstrating therapeutic activity (15). Similar results were shown for co-usage of DNX-2401 with $\gamma$-IFN (16).

The advantage of Ads lies in their ability to affect both quiescent CSCs and actively proliferating tumor cells, while chemotherapeutic drugs usually target either one or another $(17,18)$. The ability of Ads to kill CSCs has been demonstrated in numerous studies using variously modified Ad5 (19-22). Despite Ad5, being a serotype of oncolytic Ads, has been used in the vast majority of preclinical and clinical trials, it has a number of disadvantages, primarily related to its high seroprevalence (23) in humans as well as high hepatotropism (24). In this regard, the use of alternative serotypes, such as adenovirus type 6 (Ad6), which have weaker both seroprevalence and hepatotoxicity due to capability of avoiding Kuppfer cells, seems to be quite relevant (25).

Ad6 has been shown to be effective against several types of tumors including hepatocellular carcinoma, breast cancer, prostate cancer, ovarian cancer, as well as multiple myeloma (25-29). At the same time, its oncolytic potential towards GB as well as towards CSCs is still completely unknown.

The most common way to detect glioma CSCs is the FACS analysis with antibodies against certain surface antigens, such as CD133, CD15, CD44, integrin- $\alpha 6$, L1CAM and A2B5. The main disadvantage of this approach is that these antigens determine the interplay of CSCs with their microenvironment, and once such an interplay is abrogated due to dissociation of cells from their niche, the significance of the target markers is getting lost (2). Alternative approaches are based on the ability of CSCs either to form neurospheres in the serum-free medium or to efflux fluorescent dyes (4). Previously, we reported on the ability of CSCs of various origin to natively internalize fragments of extracellular double-stranded DNA (dsDNA) (3033). To detect CSCs, dsDNA fragments of human Alu-repeat fluorescently labelled with TAMRA-5-dUTP (hereinafter referred to as $A l u$-TAMRA DNA) were used as a probe in these studies. Previously, we have demonstrated that capability of internalizing extracellular DNA fragments directly coincides with the specific markers of some types of stem cells. Thereby, approximately $40 \%$ of $\mathrm{CD} 34^{+}$hematopoietic stem cells (31), $7 \%$ of $\mathrm{CD}^{+} 0^{+}$mesenchymal stem cells and $10 \%$ of induced pluripotent cells have been shown to be TAMRA-positive $\left(\mathrm{TAMRA}^{+}\right)$. Additionally, more than $60 \% \mathrm{TAMRA}^{+}$ glioblastoma cells were also positive for CD133 expression (34). Analysis of surgical specimens of primary human brain tumors revealed a positive correlation between the number of cells capable of internalizing $A l u$-TAMRA DNA (TAMRA ${ }^{+}$ cells) and the tumor grade. In other words, the higher the number of $\mathrm{TAMRA}^{+}$cells (CSCs) in the tumor sample, the more aggressive the tumor is in a patient (34). This capability of dsDNA internalization has been used as the marker of CSCs in the current report.

Since Ad6 is far less studied than Ad5 and its effect on CSCs remains unclear, a direct comparison of wild-type Ad5 and Ad6 is necessary to estimate further genomic modifications for bringing Ad6 to clinical trials. Thus, to address the potential of Ad6 to be the basis for development of new therapeutic agents against brain tumors, its oncolytic potential towards U87 glioblastoma cells in vitro and in vivo has been estimated. In addition, the content of CSCs in tumors after treatment with Ad5 and Ad6 has been evaluated by fluorescent microscopic analysis and counting of the U87 cells capable of internalizing Alu-TAMRA DNA. Results demonstrated that Ad6 has an oncolytic activity against human GB U87 cells both cultured in vitro and subcutaneously grafted into SCID mice in vivo. Analysis of CSCs (TAMRA ${ }^{+}$cells) content revealed a tendency for decrease in the number of these cells after Ad5 and Ad6 treatment, compared to the control.

\section{Materials and Methods}

Cell lines. Ad293, U87 and U251 cell lines were kindly provided by the SPF-vivarium of the Institute of Cytology and Genetics SB RAS (Novosibirsk, Russia). Cells were cultivated in DMEM (Thermo Fisher Scientific, Waltham, MA, USA) supplemented with $5 \%$ fetal bovine serume (FBS; Thermo Fisher Scientific) at $37^{\circ} \mathrm{C}$ and $5 \% \mathrm{CO}_{2}$.

Viruses. Ad5 and Ad6 strains were kindly provided by Professor P.M. Chumakov (head of the Cell Proliferation Department, Engelgardt Institute of Molecular Biology RAS, Moscow, Russia). Virus propagation was performed in Ad293 cells derived from the standard HEK293 cell line with improved cell adherence and plaque formation properties. Virus preparations were purified by centrifugation in $\mathrm{CsCl}$ gradient. Infectious particles were measured on Ad293 cells using 1:10 serial virus dilutions. On days 10-12, each well of a plate was scored for cytopathic effect (CPE) development and viral titer was calculated in $\mathrm{TCID}_{50}$ units.

Cell viability assay. The viral suspension was serially diluted in 96well plates using DMEM with $2 \%$ FBS from $10^{4}$ to $10^{-1}$ TCID $_{50}$ per cell. Further, $2 \times 10^{4}$ U87 cells/well were added and incubated for 3 days at $37^{\circ} \mathrm{C}$ and $5 \% \mathrm{CO}_{2}$. Cell viability was estimated by the Cell Proliferation Kit XTT (AppliChem, Darmstadt, Germany) accordingly to the manufacturer's recommendations. Optical density 
was measured on an iMark Microplate Absorbance Reader (BioRad, Hercules, CA, USA). The median of the optical density value in wells with untreated cells was taken as $100 \%$.

Animals. We used 6-7 week-old SCID mice housed in the SPF Animal Facility (Institute of Cytology and Genetics SB RAS). Mice were kept in OptiMice IVC cages (Animal Care Systems, Centennial, CO, USA) in special cleanrooms with HEPA14-filtered incoming air, under regular 14/10-hour light/dark cycle (lights on at 02:00 a.m.), constant room temperature of $22 \pm 2^{\circ} \mathrm{C}$, and relative humidity of $45 \pm 15 \%$. All experiments with animals were conducted in strict compliance with the principles of humanity in accordance with the European Community Council Directives (86/609/EEC) and were approved by the Animal Care and Use Committee of the Institute of Cytology and Genetics SB RAS.

Transplantation of GB cells into mice. To assess the dynamics of changes in tumors (experiment 1) and to perform pathomorphological and PCR analysis as well as CSCs qualitative assessement (experiment 2), $6.3 \times 10^{3} \mathrm{U} 87$ cells diluted in $100 \mu \mathrm{l}$ of DMEM/F12 medium were subcutaneously inoculated in the right scapula area of mice. When the tumors reached the volume of 60 (experiment 1 ) or $400 \mathrm{~mm}^{3}$ (experiment 2) first Ad injection at a dose of $10^{9} \mathrm{TCID}_{50}$ or mock DPBS in $100 \mu$ of sterile $0.9 \% \mathrm{NaCl}$ was made intratumorally with two repeats followed up in days 4 and 7 or 8 (n=6 animals per group). To assess the effect of Ads on CSCs, SCID mice were grafted with $6.3 \times 10^{3}$ U87 cells suspended in $100 \mu \mathrm{l}$ of DMEM/F12 medium. At the stage of average graft volume of 550 $\mathrm{mm}^{3}$, animals were divided into 3 groups $(\mathrm{n}=11-13$ animals per group). Ad5 and Ad6 were diluted in $7 \mu \mathrm{l}$ of sterile $0.9 \% \mathrm{NaCl}$ and injected with $10 \mu \mathrm{l}$ Hamilton syringe (Hamilton) at the dosage of $10^{8}$ TCID $_{50}$ per mouse. Mice of the control group were injected with 7 $\mu \mathrm{l}$ of pure $0.9 \% \mathrm{NaCl}$. Mice were examined 2-3 times per week, tumor volume was calculated by the formula length $\times$ width ${ }^{2} \times 0.5(35)$.

Quantification of Ad replication by PCR. Two mice from each viral group and 3 from control group were withdrawn to obtain tumor and liver samples. Tissues were homogenized and lysed with the 50 $\mathrm{mM}$ EDTA, $1 \%$ SDS supplied with $200 \mu \mathrm{g} / \mathrm{ml}$ proteinase $\mathrm{K}$ (Thermo Fisher Scientific). DNA from the obtained lysates was extracted with phenol/chloroform and precipitated with an equal volume of isopropanol. Precipitated DNA was further dissolved in $10 \mathrm{mM}$ TrisHCl, pH 8.0. Total amount of DNA in samples was assessed on QUBIT fluorimeter (Thermo Fisher Scientific). Quantitative PCR was performed on the iQ5 Multicolor Real-Time PCR Detection System (Bio-Rad) with use of SYBR Green fluorescent dye (quantitative PCRmix-HS SYBR, Evrogen, Moskow, Russia) and Bio-Rad iQ5 software. Specific primers were designed to amplify hexon sequence:

Ad5-hex-for 5'-GAAGGTCAAACACCTAAATATG-3';

Ad5-hex-rev 5'-ATTAGTTCTCGTGAGTTACCT-3';

Ad6-hex-for 5'-GACAGGGCGTTATGGTTGA-3';

Ad6-hex-rev 5'-TCCAAGCATGACTTTGGCA-3'.

The following temperature conditions were used for the reaction: $95^{\circ} \mathrm{C}$ for $3 \mathrm{~min}, 45$ cycles of $95^{\circ} \mathrm{C}$ for $10 \mathrm{~s}, 58^{\circ} \mathrm{C}$ for $20 \mathrm{~s}, 72^{\circ} \mathrm{C}$ for $1 \mathrm{~min}$, totally 45 cycles. For each experiment, the approximating function based on standardized dilutions of the viral DNA (10 fg $100 \mathrm{pg}$ ) was plotted and used for calculation of the target DNA template in the reaction. For PCR, 20 ng of sample DNA were used. Each PCR was repeated three times.
Estimation of the content of CSCs cells in vivo. To obtain dUTP-5TAMRA-labeled DNA probe, human Alu-repeat DNA was labeled with TAMRA fluorescent dye by PCR as previously described (31). Then, TAMRA ${ }^{+}$cells (CSCs) were evaluated in the body of tumor. Briefly, subcutaneous graft of U87 tumor was surgically excised; a $\sim 0.5-\mathrm{cm}^{3}$ fragment was washed with PBS and incubated in DMEM (Gibco) with $1 \mu \mathrm{g} / \mathrm{ml}$ of $A l u$-TAMRA DNA at $25^{\circ} \mathrm{C}$ for $1 \mathrm{~h}$ in the dark. Further, the tissue fragment was washed twice with PBS and frozen at $-20^{\circ} \mathrm{C}$. Several sections of the fragment were obtained on the Leica Ultracut EM UC6 ultramicrotome (Leica Microsystems, Bannockburn, IL USA) and placed on a glass slide. Preparations were treated with $\sim 10 \mu \mathrm{l}$ of Antifade DABCO (Sigma-Aldrich, Saint Louis, MO, USA) supplemented with $0.5 \mu \mathrm{g} / \mathrm{ml}$ DAPI (SigmaAldrich) and covered with cover glass. Preparations were analyzed on an LSM 780 NLO laser scanning microscope (Zeiss, Jena, Germany) with use of ZEN 2010 B SP1 software (Zeiss).

Quantitative analysis of TAMRA + cells (CSCs) in tumor samples. Subcutaneous graft of U87 tumor was surgically excised and chopped finely in a Petri dish. The obtained tissue mass was incubated in 10 volumes of PBS with $0.3 \%$ collagenase (Gibco) at $37^{\circ} \mathrm{C}$ for $1 \mathrm{~h}$. The obtained suspension was strained through $40 \mu \mathrm{m}$ cell strainer (BD Bioscience). One million freshly isolated cells were incubated in $400 \mu \mathrm{l}$ of DMEM with $0.5 \mu \mathrm{g}$ of $A l u$-TAMRA DNA at the room temperature for $1 \mathrm{~h}$ in the dark. After this, cells were precipitated at $400 \times g$ for $5 \mathrm{~min}$ at $25^{\circ} \mathrm{C}$, washed with small volume of medium and resuspended in the final volume of medium. Cell suspension was applied to glass slide by cytospin at $1000 \mathrm{rpm}$ for 1 min. Then preparations were treated with $\sim 10 \mu \mathrm{l}$ of Antifade DABCO supplemented with DAPI $(0.5 \mu \mathrm{g} / \mathrm{ml})$ and covered with cover glass. Preparations were analyzed using the AxioVision fluorescent microscope (Zeiss) with the use of ZEN software (Zeiss). The FITC channel was used to discriminate the false positive red signal associated with broadband autofluorescence of some portion of cells. For each tumor sample, two preparations were made. For each preparation, 500-3000 cells were analyzed. The number of animals in groups for each examination point was 3-4.

Pathomorphological analysis. Pieces of organs were fixed in $4 \%$ formaldehyde, dehydrated in a graded series of alcohol, cleared in xylol, and embedded in paraffin. Paraffin sections of $5 \mu \mathrm{m}$ were stained with hematoxylin and eosin. An AxioImager ZI microscope (Zeiss) was used for imaging.

Statistical analysis. Statistical analysis was performed with Statistica 10 package (StatSoft, Tulsa OK, USA). In the plots, median \pm standard error (SEM) or median \pm standard deviation (SD) values are shown. Statistical significance was estimated by the Mann-Whitney test. The MannWhitney $U$-test was used, since this nonparametric criterion allows to compare small samples with a non-Gaussian distribution. Pearson's correlation coefficient was calculated by Statistica 10. Statistical significance was calculated for experimental samples relatively to control. Difference was considered confident at $p<0.05$ or $p<0.01$.

\section{Results}

Estimation of the oncolytic effect of Ad6 against glioblastoma cells. Oncolytic capabilities of various adenoviral serotypes, including Ad6, have been estimated on a variety of cell lines, such as ALMC-1, ALMC-2, 

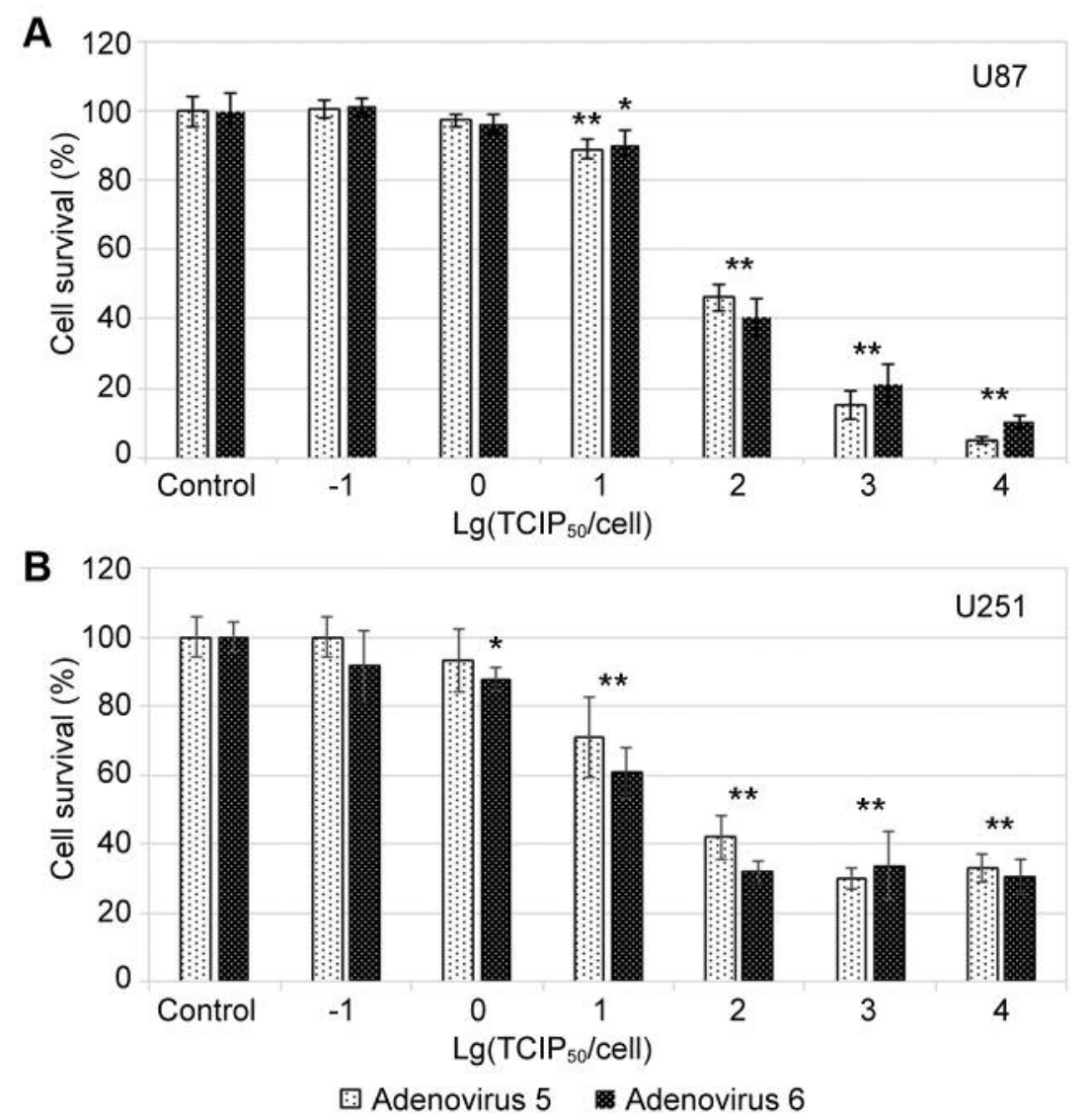

Figure 1. Cytotoxicity of adenovirus serotype type 5 (Ad5) and Ad6 against the human glioblastoma cell lines U87 (A) and U251 (B). Median \pm SD values shown (n=6). Statistical significance of the differences between control and experimental groups was verified by the Mann-Whitney test, $* p<0.05, * * p<0.01$.

ANBL-6, HepG2, Hep3B, Huh7, PC3, LNCaP, DU145, MDA-MB-231, MDA-MB-468, SKBr3, BT-474, SKOV3, OVCAR-3 (25-29). However, oncolytic potential of Ad6 against GB has not yet been evaluated. Such an investigation should be conducted prior to modifying the virus genome to enhance its oncolytic efficacy. In our study we have used U87 and U251 cell lines as a cellular model, while for the comparative analysis of Ad6 oncolytic efficacy we have used the wild-type Ad5 as being one of the most investigated.

U87 and U251 cells were seeded $\left(2 \times 10^{4}\right.$ cells/well $)$ in a 96-well plate and supplied with viruses, with $\mathrm{TCID}_{50}$ per cell ranged from $10^{4}$ to $10^{-1}$ at dilution multiplier 10. Cell viability was assessed by the XTT-test after a complete CPE in the wells with maximal $\mathrm{TCID}_{50} /$ cell. Dose-dependent viability of cells is shown in Figure 1.

As it is noticeable from Figure 1, the lytic effect of Ad6 is similar to that of Ad5, while significantly $(p<0.01)$ differing from the control.
Estimation of oncolytic efficacy of Ad6 against glioblastoma cells in vivo. Intracerebral and subcutaneous grafting of the investigated GB cell line into immunodeficient mice remains to be among the most common approaches for evaluating the efficiency of the used therapy towards GB cells (36). Intracerebral grafts representing a model that is more approximated to the reality have a number of disadvantages, including inaccessibility of tumors for continuous monitoring, and mortality of experimental animals with tumors of even a relatively small volume (not more than 100 $\mathrm{mm}^{3}$ ). Since the majority of procedures, such as estimation of therapeutic effects of Ads, pathomorphological assays as well as counting the CSCs in tumor samples, required a relatively large number of cells, we have used the model of subcutaneous grafting of U87 cells into SCID mice. Additionally, since the present work on comparing the activity of two Ad serotypes is the first such investigation, the orthotopic grafting as a more complex version of xenotransplantation is planned to be carried out in the further 


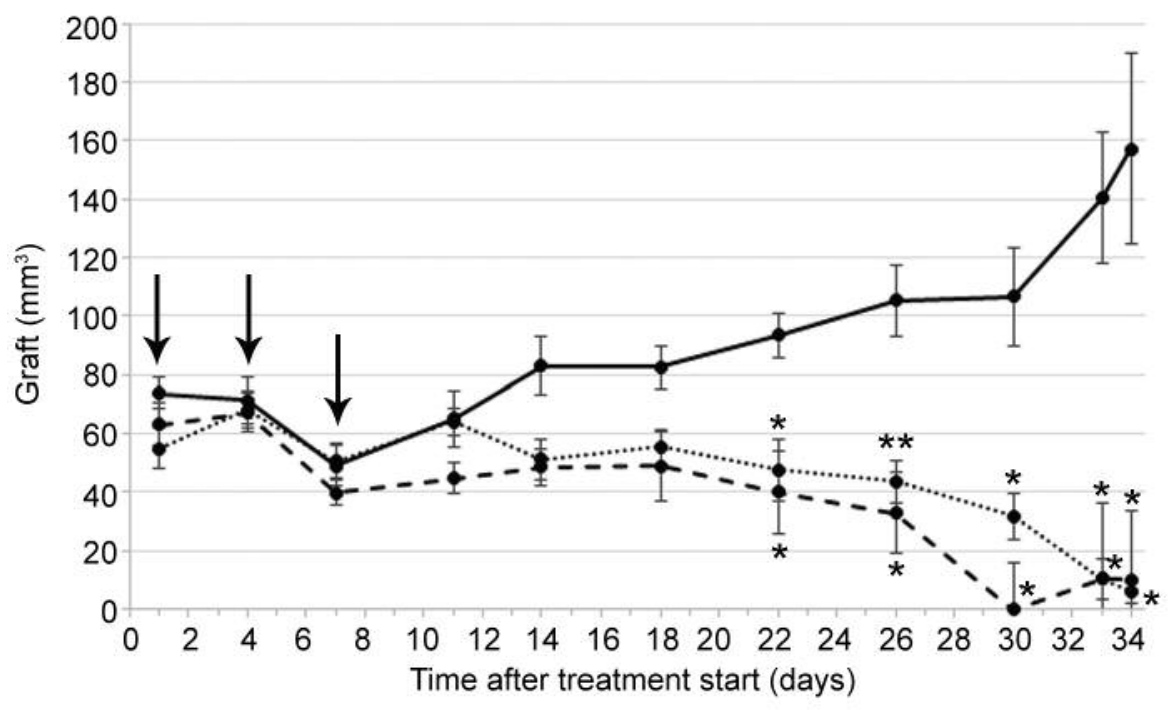

$\multimap$ Control $-\bullet-$ Adenovirus $5 \quad \cdots \bullet \cdot$ Adenovirus 6

Figure 2. Examination of tumors developed from U87 human glioblastoma cells subcutaneously grafted into SCID mice in the course of therapy with preparations of adenovirus serotype 5 (Ad5) and Ad6. The graph represents the tumor growth rate (median \pm SEM, $n=9-10)$. Statistical significance between the experimental and control groups was estimated with the Mann-Whitney test, $* p<0.05 ; * * p<0.01$. Arrows denote the days of adenovirus injections.

works on a more thorough comparative analysis of the properties of Ad5 and Ad6 viruses.

In the first experiment once xenografts reached the average volume of $60 \mathrm{~mm}^{3}$, the first injection of Ad5 and Ad6 with dose of $10^{9}$ TCID $_{50}$ was performed (day 1) followed by two more injections on the 4th and 7 th day of therapy (Figure 2). Viruses were administered in triple since the repeating treatment of the tumor area with Ads in the course of therapy induces a more intensive immune response (37). The experiment was stopped on day 34 for ethical reasons regarding animals of the control group. The xenograft volumes of the experimental groups that received Ad6 or Ad5 were significantly lower compared to those of the control group $(p<0.05$, Mann Whitney test), on days 22 to 34 of therapy. It should be noted that there were some animals, in which tumors became undetectable ( 3 animals in the Ad5 group and 2 in the Ad6 group). Thus, the oncolytic efficacy of Ad6 against the U87 glioblastoma cells was concluded to be similar to that of $\mathrm{Ad} 5$.

The second experiment was done to perform pathomorphological and PCR analysis of tumors as well as CSCs qualitative assessment. The treatment was started with subcutaneous grafts of a bigger initial average volume approximately $400 \mathrm{~mm}^{3}$ instead of $60 \mathrm{~mm}^{3}$. Dynamics of tumors growth is represented as the ratio of the current tumor size to the initial one, measured prior to the start of therapy (Figure 3). It was found that Ad6 demonstrated significant oncolytic power ( $p<0.01$, compared to the control group). Ad5 also led to decreased tumor size, however without statistical significance (compared to the control).

Viral replication in the tumor tissues was confirmed with quantitative PCR. For this purpose, total DNA from livers and tumors of the tested animals ( 2 mice from both the Ad5 and Ad6 groups and 3 mice from the control group) was isolated and further quantitatively tested for the presence of viral DNA (Table I). Viral DNA was not detected in livers of all tested animals as well as in tumors of animals from the control group. At the same time, DNA isolated from tumors of the treated mice was shown to contain specific (Ad5 and Ad6) viral DNA.

For additional estimation of the Ad efficiency, a pathomorphological assay of the tumor samples was performed (Figure 4). A hallmark of this type of tumors is a formation of multiple sockets, strands, "pearls" (concentrically aggregated keratin indicating the unaffected ability of tumor cells to keratinize, which, in turn, indicates a sufficient degree of differentiation), as well as the presence of cribriform areas (vacuolized fragments of tumor tissue) (Figure 4A, B). In one of the control group samples, tumor cells were detected in the blood vessel lumen (Figure 4C), indicating a possible tumor metastasis.

Samples of tumors from the Ad5 group were characterized by proliferation of the blood vessels of adipose tissue that surrounds the tumor node. It is manifested as the endothelium 
Table I. Quantitative detection of adenovirus serotype 5 (Ad5) and adenovirus serotype 6 (Ad6) viral DNA in liver and tumor tissues of treated (subjected to adenoviral administration) and control mice.

\begin{tabular}{|c|c|c|c|c|}
\hline Group & Organ & Mice (n) & Amount of Ad5 DNA (pg) & Amount of Ad6 DNA (pg) \\
\hline \multirow[t]{4}{*}{ Ad5-treated } & \multirow[t]{2}{*}{ Liver } & $5 \_2$ & Not detected & Not detected \\
\hline & & $5 \_3$ & Not detected & Not detected \\
\hline & \multirow[t]{2}{*}{ Tumor } & $5 \_2$ & $16.67 \pm 0.05$ & Not detected \\
\hline & & $5 \_3$ & $1.83 \pm 0.03$ & Not detected \\
\hline \multirow[t]{4}{*}{ Ad6-treated } & \multirow[t]{2}{*}{ Liver } & $6 \_1$ & Not detected & Not detected \\
\hline & & $6 \_2$ & Not detected & Not detected \\
\hline & \multirow[t]{2}{*}{ Tumor } & $6 \_1$ & Not detected & $156.57 \pm 1.53$ \\
\hline & & $6 \_2$ & Not detected & $8.77 \pm 0.10$ \\
\hline \multirow[t]{3}{*}{ Control } & \multirow[t]{3}{*}{ Liver } & 1 & Not detected & Not detected \\
\hline & & 2 & Not detected & Not detected \\
\hline & & 3 & Not detected & Not detected \\
\hline
\end{tabular}

basophilia (it darkens upon staining) and a certain polymorphism of the contours of lumens (Figure 4D). In tumor samples there are few small focuses of necrosis and granulation tissue. For quantification of the tumor necrosis spreading, the ratio of necrotic tissue area to the total section area was calculated. For each case, not less than 10 randomly selected sections were analyzed. Total necrotic area in the Ad5 group did not exceed $10 \%$ of the section area. Tumor, similarly to the control, was characterized by formation of cellular associations such as trabeculae, sockets, pearl-like structures and cribriform sites (Figure 4E).

In the case of tumors treated with Ad6, a more pronounced, if compared with Ad5 treated ones, necrosis of tumor tissue was observed (Figure 4F); tumor necrotic area constituted about $50 \%$ of the total sections area. This could indicate an increased therapeutic effect of Ad6. On the other hand, estimation of the necrosis degree could be an additional marker of therapeutic efficacy as it was repeatedly reported that a simple decrease in the tumor volume is not an unambiguous indication of the oncolytic virus effectiveness (38). This observation, however, is to be verified with a number of additional assays. In the necrosis free areas, the microstructure of the tumor contains a number of peculiarities (sockets, "pearls", cribriform areas) (Figure 4G).

Investigation of the Ad6 and Ad5 effect on tumor stem cells in vivo. Prior to estimation of the oncolytic efficacy of Ad5 and Ad6 on CSCs, the presence of these cells in tumor samples was qualitatively assessed. The previously described ability of CSCs to internalize the fluorescent DNA probe (Alu-TAMRA DNA) $(31,33)$ allows a visual detection of these cells in sections of tumor tissue. Moreover, this approach makes it possible to determine a spatial organization of CSCs in the bulk of tumor cells, which is another intriguing issue in tumor biology. A fragment of tumor was excised and treated as described in

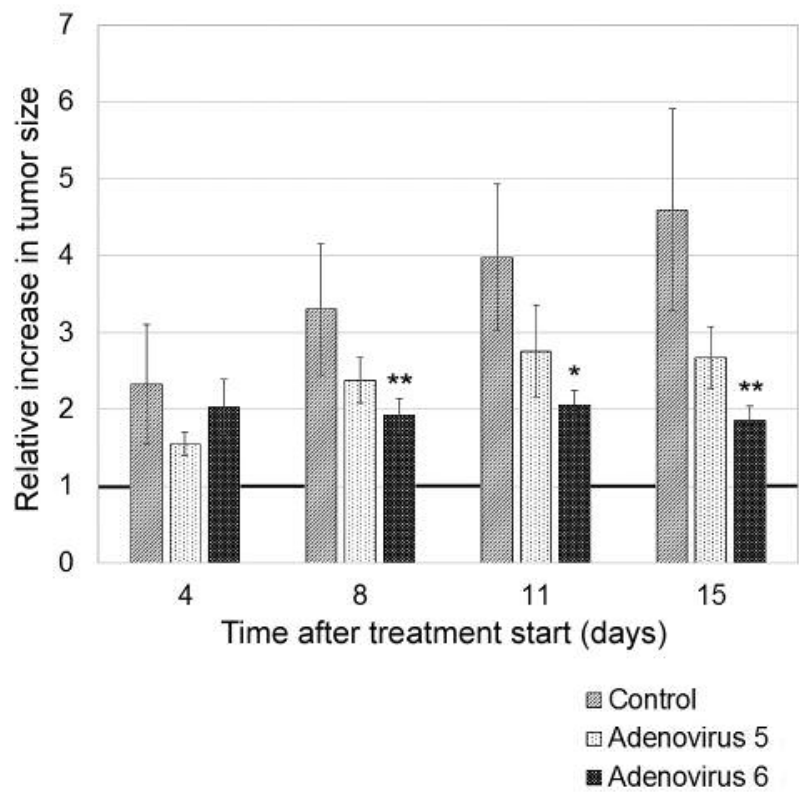

Figure 3. Examination of tumors developed from U87 human glioblastoma cells, subcutaneously grafted into SCID mice, in the course of therapy with adenovirus serotype 5 (Ad5) and Ad6. Dynamics of tumor growth (Median \pm SEM, $n=6-8$ ). $Y$ axis represents the ratio of the current tumor size to the initial one, measured prior to the start of therapy and taken as 1 (black baseline). Ad5 and Ad6 were administered at day 1, 4 and 8. Statistical significance between the experimental and control groups was estimated with the Mann-Whitney test, ${ }^{*} p<0.05$, $* * p<0.01$.

"Materials and Methods" section. A series of frozen sections was examined using the laser scanning microscope.

The analysis revealed that in the U87 human GB tumors of the control group, CSCs are aggregated into groups consisting of several cells (average $\pm \mathrm{SD}$ is 10.1 \pm 6.8 ), which were located 

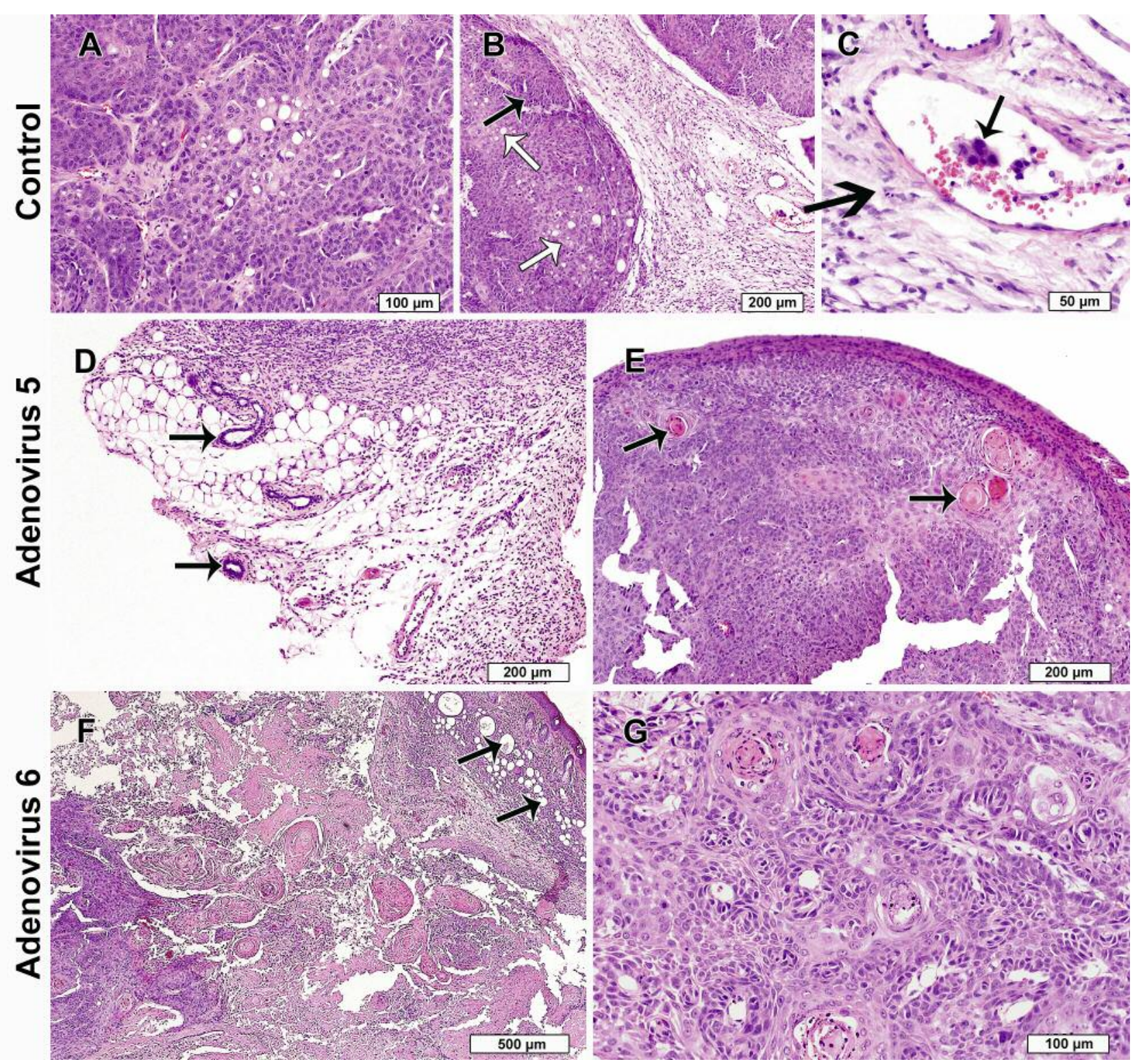

Figure 4. Pathomorphological assays of tumors developed from U87 human GB cells, subcutaneously grafted into SCID mice, after the course of therapy with adenovirus serotype 5 (Ad5) and Ad6. Control: Among polymorphic cellular structures, there are cribriform areas (in the center of the micrograph) (A); the wide band of a granulation tissue as a response to the necrotic changes. Conglomerates of the tumor exhibit "pearl" formation (white arrows) and cribriform areas (black arrows) (B); zoomed fragment of micrograph B shows aggregation of tumor cells in the lumen of a blood vessel (arrow) (C). Adenovirus 5: Subcutaneous adipose tissue with multiple blood vessels, some of which exhibit endothelial proliferation (arrows) (D); tumor of typical morphology: some "pearl" structures (arrows) appeared among dense cellular aggregations (E). Adenovirus 6: Necrosis and decay of subcutaneous tumor node. Inflammatory infiltration of the skin's deep layers and severe dystrophic alterations in the epithelial appendages (arrows) $(F)$. Characteristic details of the tumor microstructure $(G)$.

both on the periphery (Figure 5A) and in the full thickness of the tumor section (Figure 5B). Presence of CSCs was also detected in tumors treated with Ad5 and Ad6, but in this case, in contrast to untreated tumors with conglomerates of CSCs, solitary cells could only be observed (Figure 5C, D).
U87 cells were subcutaneously grafted into SCID mice. The first administration of the virus was on the 30th day when tumors reached the average volume of $550 \mathrm{~mm}^{3}$; this volume was chosen due to technical need to have a sufficient amount of tumor tissue for the quantitative analysis of CSCs. 


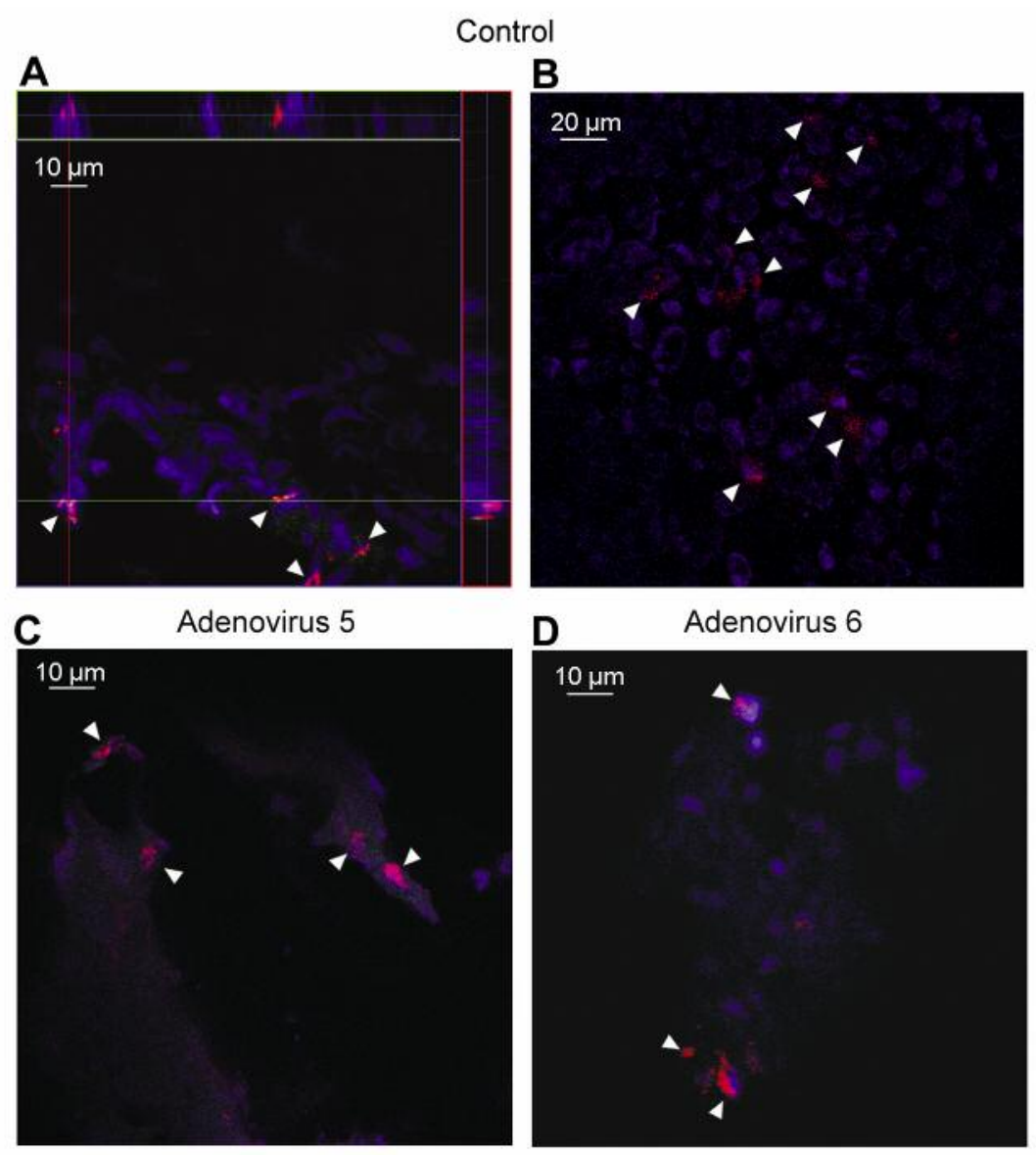

Figure 5. Distribution of TAMRA+ cells (cancer stem cells; CSCs) on sections of U87 tumor detected with laser scanning microscope. In the control tumor, aggregations of TAMRA+ cells are detected both on the periphery of the section $(A)$ and in the full-thickness tumor $(B)$. In tumors treated with adenoviruses, solitary cells in the full-thickness tumor are only detected $(C, D)$. TAMRA ${ }^{+}$cells are pointed with arrows.

Viruses were administered 3 times (on the 1st, 2nd and 4th day). Since the oncolytic effect of the viral preparations was previously reported to be quite high and producing a risk of tumor lysis before the number of CSCs could be quantified, we decided to lower the viral dose up to $10^{8} \mathrm{TCID}_{50}$ per mouse. To trace the changes in CSCs content in tumors, 3 or 4 mice from each group were taken on days 7, 10, and 14 since the therapy started. Cells from tumors were incubated with $A l u$-TAMRA DNA as it is described in "Materials and Methods" section. Counting CSCs $\left(\right.$ TAMRA $^{+}$cells) was performed using the fluorescent microscope (Figure 6A).

Changes in CSCs content on days 7, 10, and 14 after the start of therapy with Ads are shown in Figure 6B. On the 7th day, CSC content in tumors treated with Ad6 as compared with those treated with Ad5 decreased $(p<0.05)$. On the 10th day, the number of CSCs in both treated groups was equalized, but there was a significant difference between Ad5 and control groups $(p<0.05)$. At the final stage of the experiment, the percentage of CSCs in groups treated with Ads remained equal, there were no significant differences from the control, but a reducing in TAMRA+ cells content can be seen on the graph (Figure 6B, the right panel).

In addition, we have estimated the dependence of tumors "growth rate" on the content of CSCs during the analysis. The "growth rate" is referred to as the ratio of the tumor size on the day of the experiment to the size of xenograft 3 days before (tumor tissue growth rate). A ratio less than or equal to 1 was regarded as a complete absence of growth or even regression, a ratio from 1 to 1.2 was regarded as almost zero growth, a rate from 1.2 to 1.35 was regarded as moderate growth, a ratio greater than or equal to 1.35 was regarded as active growth. Each group was assigned with a nominal value from 1 to 4 .

As it follows from the data in Figure 7, the fast-growing tumors have a higher percentage of CSCs $(p<0.05)$. Moreover, Pearson's correlation coefficient between groups 1 ("regression") and 4 ("active growth") was 0.76 , (Figure 


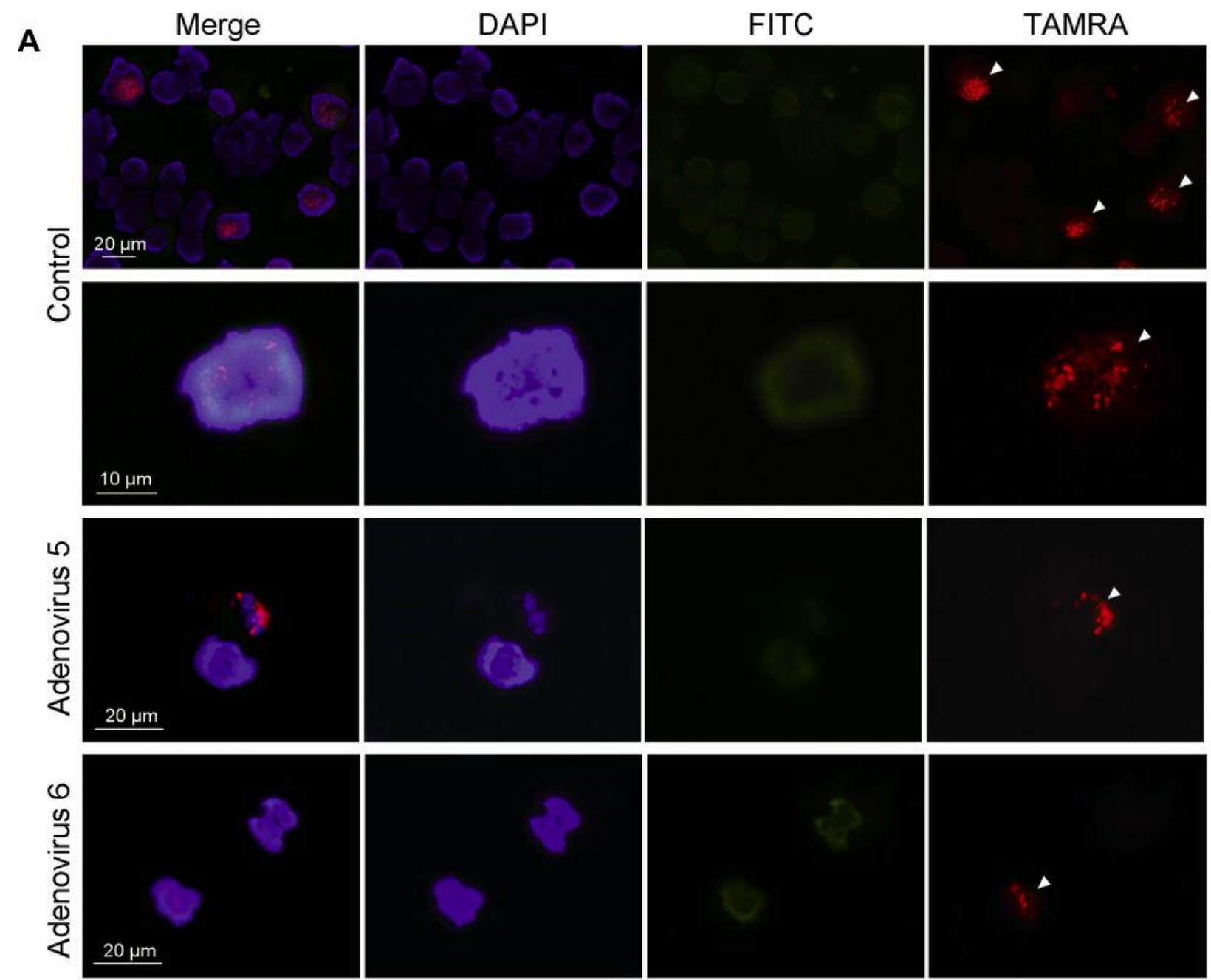

B

7th day after first adenovirus injection 10th day after first adenovirus injection 14th day after first adenovirus injection
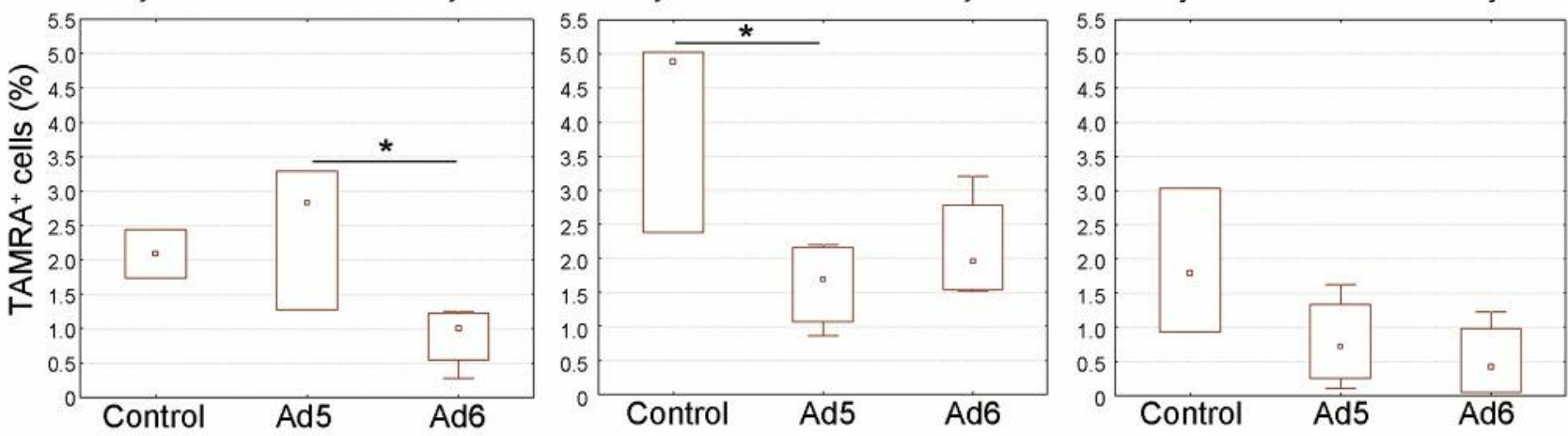

- Median $\square 25-75 \%$ I Non-outlier range

Figure 6. Analysis of TAMRA+ cells (cancer stem cells; CSCS) content in samples of U87 tumor after treatment with adenovirus serotype 5 (Ad5) and Ad6. Representative images of fluorescent microscopy show TAMRA+ cells (red), autofluorescence (FITC), and cell nuclei (DAPI) in cells from tumors untreated or treated with Ad5 and Ad6. Cells that internalized Alu-TAMRA DNA are marked with arrows (A). Graphs present the content of TAMRA ${ }^{+}$cells on days 7, 10, and 14 after the start of therapy. The content of TAMRA ${ }^{+}$cells in treated tumors tends to decrease. Statistical significance between the Ad5 and Ad6 groups (1st graph) and Control and Ad5 groups (2nd graph) was estimated with the Mann-Whitney test, $* p<0.05$. 
7), indicating a correlation of subcutaneous U87 graft "growth rate" with the number of detected CSCs.

\section{Discussion}

Ads were shown to be promising oncolytic agents in numerous preclinical and clinical studies (39). High seroprevalence of Ad5 implies a need to search for alternative, rare serotypes, whose oncolytic efficacy would not be inferior to Ad5, but at the same time, would possess additional useful features to be used as oncolytics. The currently reported Ad6 is considered to be among such promising serotypes. It has been shown that Ad6 is a less seroprevalent, and neutralizing antibodies against Ad5 are not cross-reactive with Ad6 (40). In vitro and in vivo assays performed on cell lines and xenografts of mammary gland, prostate, ovary and liver tumors as well as on multiple myeloma proved its high oncolytic effect as compared to many other serotypes (25-29). It is also important to note the high hepatotropism of Ad5; being administered intravenously to mice $90 \%$ of viral particles are inactivated by liver macrophages within $24 \mathrm{~h}$ (41). In contrast, Ad6, as it has been shown in some studies, is resistant to Kupffer cells due to a different hexon structure $(24,25)$. In vivo experiments revealed a 30 -fold less damage of liver upon intravenous administration of Ad6, compared to Ad5 (42).

These facts presume Ad6 to be a promising agent in treating malignant tumors. However, the anti-tumor effect of Ad6 against GBs has not yet been studied. In this article, we report the results of a study conducted both in vitro on the models of U87 and U251 cell lines, and in vivo on the model of subcutaneous grafts of U87 in SCID mice.

In vitro investigation of the oncolytic properties of Ad6 against U87 and U251 GB cells yielded results comparable to those for Ad5. Being applied with a dose of 1 $\lg \left(\right.$ TCID $_{50} /$ cell $)$ both Ad5 and Ad6 exerted a cytotoxic effect against U87 ( $p<0.01$ and $p<0.05$ correspondingly) and U251 $(p<0.01)$ cells in vitro.

In vivo experiments were conducted in two variants: with adenoviral therapy started with the small average tumor volume $-60 \mathrm{~mm}^{3}$ (Figure 2) and with big one $-400 \mathrm{~mm}^{3}$ (Figure 3). As a result, in both cases Ad6 was established to induce an oncolytic effect similar or higher to that of Ad5.

Pathomorphological assays revealed the necrotic sites in tumors in mice of both control and treated groups, and the highest degree of necrosis was found in the group of Ad6. Necrosis in the tumors of the control group could be due to their rapid growth causing the large tumor volumes with possible foci of hypoxia and trophic impairments in the "cores" of tumors, which could be a result of insufficient vascularization (43).

In the case of adenovirus-affected tumors, the necrotic processes are more pronounced due to virus replication and

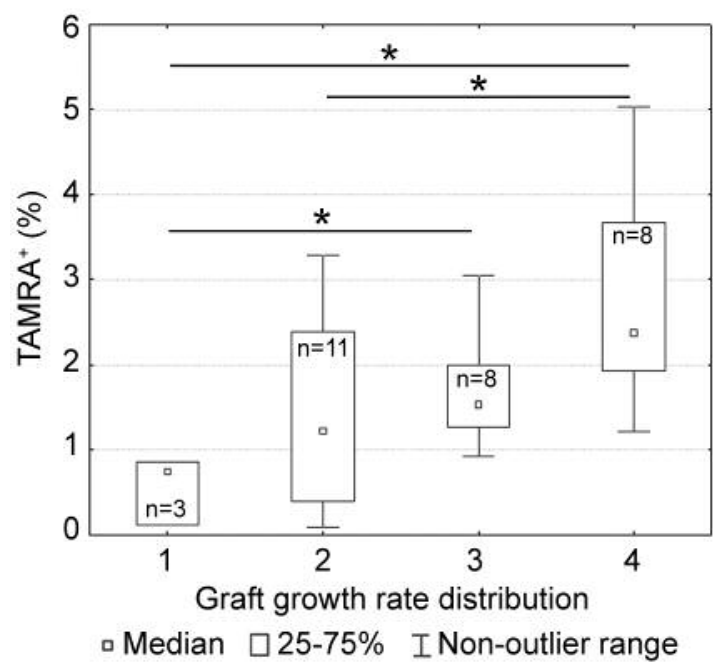

Figure 7. Correlation between the growth rate and content of TAMRA ${ }^{+}$ cells (cancer stem cells; CSCs) in human U87 glioblastoma, subcutaneously grafted into SCID mice. 1 - complete absence of growth or regression; 2 - almost zero growth; 3 - moderate growth; 4 -active growth. Pearson's correlation coefficient between groups 1 and 4 was 0.76. Statistical significance between the groups (indicated by horizontal lines) was estimated with the Mann-Whitney test, ${ }^{*} p<0.05$.

consequent lysis of tumor cells (44). It was found that upon the replication of Ad5 in U87 cells, they are lysed both due to the L3 adenoviral protease-mediated cleavage of cytokeratin 18 (K18) and the E3 11.6-kDa adenovirus death protein (ADP), as well as due to autophagy (45). These lytic processes induce the immunogenic cell death (ICD) that, in turn, results in the activation of antitumor immune response (46). An elevated necrosis level observed in Ad6treated tumors could testify to the advantages of this serotype in replication and lysis of tumor cells in xenografts (size of tumors treated with Ad5 and Ad6 is mostly the same).

It is known that the histologically detected necrosis can be terminal stage of apoptosis or autophagy (47). This type of necrosis is known as secondary and is observed when the cell death rate exceeds the ability of the organism to phagocytize them (48). In our experiments, the secondary necrosis could develop due to a number of reasons, among which are: the topography of a tumor (subcutaneously located), its large volume and, as a consequence, a large number of autophagically active cells, as well as the deficiency of scavenger cells.

It should be noted that in contrast to apoptotic, necrotic cell death, is inevitably associated with inflammatory processes, and phagocytosis of cellular debris induces the full-scale immune response providing additional therapeutic advantages in the context of neoplastic diseases. 
Therapeutic benefits of necrotic cell death become even more obvious in the light of CSCs existence, since they are implicated in metastasis as well as in chemo- and radioresistance. The majority of the accepted therapeutic schemes are based on the initiation of the apoptotic program in the tumor cells, however these schemes are ineffective against CSCs, which are resistant to apoptosis (49). Moreover, antitumor compounds are often aimed against actively proliferating cells, while CSCs are capable of keeping quiescence for a long time (50). The implication of viral agents capable of infecting and killing both actively proliferating and quiescent cells seems to be quite promising in this regard.

Despite wide implication of adenoviral agents in treating malignant neoplasms, the data on their influence over CSCs, and glioma CSCs in particular, is critically limited. JIMT-1 breast ductal adenocarcinoma cell line was shown under regular conditions to contain $10 \% \mathrm{CSCs}\left(\mathrm{CD} 44^{+} / \mathrm{CD} 24^{-/ \text {low }}\right)$. After transplantation of sorted cells into mice, tumors in control groups on day 48 contained the same $10-11 \%$ CSCs, while in tumors in mice treated with recombinant Ads their content reduced to $1 \%$ (20). Yano et al. have demonstrated that the content of CSCs $\left(\mathrm{CD} 133^{+}\right)$in radioresistant MKN45 and MKN7 human stomach cancer cell lines treated with modified Ad5 (OBP-301) is lower than in these cells exposed to cisplatin or radiation (51). In another research, it has been shown that CSCs (those producing neurospheres) isolated from tumors of GB multiforme patients were susceptible to infection with recombinant Ad5 (Delta-24-RGD) both in vitro and in vivo (52).

In the present research, the first comparative analysis of Ad5 and Ad6 oncolytic effects towards GB CSCs has been conducted. The reduction of tumors to an undetectable state observed in some Ad6 treated mice could indirectly testify to complete elimination of CSCs. To make this statement confident, however, the relapse analysis is required (32). Moreover, to estimate the oncolytic efficacy of Ads towards CSCs, we have attempted to trace the changes in CSCs content in the treated tumors. For this purpose, CSC content in preparations of tumors taken from treated mice at each of three consecutive time control points (3-4 mice per each time point) was quantified.

To detect CSCs, the recently discovered ability of these cells to internalize TAMRA-labeled dsDNA was used $(31,33)$. High selectivity of exogenous dsDNA internalization into CSCs, demonstrated for both the human glioma biopsy samples (34) and the primary human GB cell lines (53), should be noted. In addition, we have conducted preliminary experiments on detecting $A l u$-TAMRA DNA probeinternalizing cells in U87 human GB cells cultured in vitro (data not shown). The approach for detection of CSCs in subcutaneous U87 xenografts proved to be adequate and valid.

On day 7 after the first viral administration, a confident decrease was found in the number of CSCs in tumors treated with Ad6 relatively to those treated with Ad5 $(p<0.05)$. This could indicate a more rapid response of the tumor to the action of Ad6. At the following checkpoints, the number of CSCs in both treated groups equalized and tended to decrease as compared to the control group. These results were consistent with those previously reported for Ad5 and its recombinants (52). Moreover, the observed correlation of subcutaneous U87 graft "growth rate" with the number of detected CSCs was also consistent with the previously demonstrated correlation between the number of CSCs and malignancy grade of gliomas in patients (34).

The results of the presented research confirm the susceptibility of both the bulk of tumor cells and CSCs of U87 human glioblastoma to Ad6. Incomplete elimination of CSCs indicates the necessity of further Ad6 genome modifications aimed not only on enhancing immunomodulating capabilities, but also on specific targeting CSCs by, for example, inserting a CD133-recognizing motif into the fiber gene. Nevertheless, Ad6 proved itself as a promising oncolytic agent for treating gliomas.

\section{Conflicts of Interest}

The Authors declare that they have no conflicts of interest.

\section{Authors' Contributions}

MVR and EVD performed the analysis, interpreted the data, and drafted the manuscript, IDO, GSR, MSS and ASP carried out the molecular studies, YRE and SIB directed the work on microscopy, EAP participated in the design of the study, OST and VVO performed pathological analysis of animal organs and tissues and interpreted the data, GVK participated in the design of the study, AAG, ELZ and IAR carried out experiments with animals, SVN participated in the study coordination and provide the technical conditions for the performed works, SSB conceived the study, participated in its design, and coordinated and drafted the manuscript. All Authors reviewed, critically revised the final manuscript. All Authors read and approved the final manuscript.

\section{Acknowledgements}

This study was supported by the State Project of the Institute of Cytology and Genetics \# 0324-2019-0042, State Project \#6.5546.2017 of Novosibirsk State University, top-100 Program Funding of the same University and the grant \#18-34-20016 of the Russian Foundation for Basic Research.

\section{References}

1 Ramirez YP, Weatherbee JL, Wheelhouse RT and Ross AH: Glioblastoma multiforme therapy and mechanisms of resistance. Pharmaceuticals 6: 1475-1506, 2013. PMID: 24287492. DOI: 10.3390/ph6121475

2 Lathia J, Mack S, Mulkearns-Hubert E, Valentim C and Rich J: Cancer stem cells in glioblastoma. Genes Dev 29(12): 12031217, 2015. PMID: 26109046. DOI: 10.1101/gad.261982.115 
3 Sánchez LM: Glioblastoma: Multidisciplinary treatment approaches. Appl Radiat Oncol 5(1): 17-25, 2016.

4 Gilbert C and Ross A: Glioma stem cells: Cell culture, markers and targets for new combination therapies. J Cell Biochem 108(5): 1031-1038, 2009. PMID: 19760641. DOI: 10.1002/jcb.22350

5 Beier D, Hau P, Proescholdt M, Lohmeier A, Wischhusen J, Oefner PJ, Aigner L, Brawanski A, Bogdahn U and Beier CP: $\mathrm{CD}^{2} 3^{+}$and $\mathrm{CD} 133^{-}$glioblastoma-derived cancer stem cells show differential growth characteristics and molecular profiles. Cancer Res 67(9): 4010-4015, 2007. PMID: 17483311. DOI: 10.1158/0008-5472.CAN-06-4180

6 Qiang L, Yang Y, Ma YJ, Chen FH, Zhang LB, Liu W, Qi Q, Lu $\mathrm{N}$, Tao L, Wang XT, You QD and Guo QL: Isolation and characterization of cancer stem like cells in human glioblastoma cell lines. Cancer Lett 279(1): 13-21, 2009. PMID: 19232461. DOI: $10.1016 /$ j.canlet.2009.01.016

7 Rycaj K and Tang DG: Cancer stem cells and radioresistance. Int J Radiat Biol 90(8): 615-621, 2014. PMID: 24527669. DOI: 10.3109/09553002.2014.892227

8 Schreck KC, Taylor P, Marchionni L, Gopalakrishnan V, Bar EE, Gaiano N and Eberhart CG: The Notch target Hes1 directly modulates Gli1 expression and Hedgehog signaling: a potential mechanism of therapeutic resistance. Clin Cancer Res 16(24): 6060-6070, 2010. PMID: 21169257. DOI: 10.1158/10780432.CCR-10-1624

9 Chen J, Li Y, Yu TS, McKay RM, Burns DK, Kernie SG and Parada LF: A restricted cell population propagates glioblastoma growth after chemotherapy. Nature 488(7412): 522-526, 2012. PMID: 22854781. DOI: 10.1038/nature11287

10 Zhu G, Su W, Jin G, Xu F, Hao S, Guan F, Jia W and Liu F: Glioma stem cells targeted by oncolytic virus carrying endostatin- angiostatin fusion gene and the expression of its exogenous gene in vitro. Brain Res 1390: 59-69, 2011. PMID: 21443868. DOI: 10.1016/j.brainres.2011.03.050

11 Mantwill K, Naumann U, Seznec J, Girbinger V, Lage H, Surowiak P, Beier D, Mittelbronn M, Schlegel J and Holm PS: YB-1 dependent oncolytic adenovirus efficiently inhibits tumor growth of glioma cancer stem like cells. J Transl Med 11: 216, 2013. PMID: 24044901. DOI: 10.1186/1479-5876-11-216

12 Lang FF, Conrad C, Gomez-Manzano C, Alfred Yung WK, Sawaya R, Weinberg JS, Prabhu SS, Rao G, Fuller GN, Aldape KD, Gumin J, Vence LM, Wistuba I, Rodriguez-Canales J, Villalobos PA, Dirven CMF, Tejada S, Valle RD, Alonso MM, Ewald B, Peterkin JJ, Tufaro F and Fueyo J: Phase I study of DNX-2401 (delta-24-RGD) oncolytic adenovirus: replication and immunotherapeutic effects in recurrent malignant glioma. J Clin Oncol 36(14): 1419-1427, 2018. PMID: 29432077. DOI: 10.1200/JCO.2017.75.8219

13 Chiocca EA, Abbed KM, Tatter S, Louis DN, Hochberg FH, Barker F, Kracher J, Grossman SA, Fisher JD, Carson K, Rosenblum M, Mikkelsen T, Olson J, Markert J, Rosenfeld S, Nabors LB, Brem S, Phuphanich S, Freeman S, Kaplan R and Zwiebel J: A phase I open-label, dose-escalation, multi-institutional trial of injection with an E1B-attenuated adenovirus, ONYX-015, into the peritumoral region of recurrent malignant gliomas, in the adjuvant setting. Mol Ther 10(5): 958-966, 2004. PMID: 15509513. DOI: 10.1016/j.ymthe.2004.07.021

14 Koski A, Bramante S, Kipar A, Oksanen M, Juhila J, Vassilev L, Joensuu T, Kanerva A and Hemminki A: Biodistribution analysis of oncolytic adenoviruses in patient autopsy samples reveals vascular transduction of noninjected tumors and tissues. Mol Ther 23(10): 1641-1652, 2015. PMID: 26156245. DOI: $10.1038 / \mathrm{mt} .2015 .125$

15 Alonso MM, García-Moure M, Gonzalez-Huarriz M, Marigil M, Hernandez-Alcoceba R, Buñales $M$, Hervás S, Gallego J, Gomez-Manzano C, Fueyo J, Lang F, Peterkin J, Diez-Valle R and Tejada S: Abstract CT027: Oncolytic virus DNX-2401 with a short course of temozolomide for glioblastoma at first recurrence: Clinical data and prognostic biomarkers. In: Proceedings of the American Association for Cancer Research Annual Meeting, Cancer Research 77: CT027, 2017. DOI: 10.1158/1538-7445.AM2017-CT027

16 Lang FF, Tran ND, Puduvalli VK, Elder JB, Fink KL, Conrad CA, Yung WKA, Penas-Prado M, Gomez-Manzano C, Peterkin $\mathrm{J}$ and Fueyo $\mathrm{J}$ : Phase $1 \mathrm{~b}$ open-label randomized study of the oncolytic adenovirus DNX-2401 administered with or without interferon gamma for recurrent glioblastoma. J Clin Oncol 35(15_suppl): 2002-2002, 2017. DOI: 10.1200/JCO.2017.35.15_suppl.2002

17 Chaurasiya S, Chen NG and Warner SG: Oncolytic virotherapy versus cancer stem cells: A review of approaches and mechanisms. Cancers (Basel) 10(4): E124, 2018. PMID: 29671772. DOI: $10.3390 /$ cancers 10040124

18 Ribacka C, Pesonen S and Hemminki A: Cancer, stem cells, and oncolytic viruses. Ann Med 40(7): 496-505, 2008. PMID: 18608120. DOI: $10.1080 / 07853890802021342$

19 Bauerschmitz GJ, Ranki T, Kangasniemi L, Ribacka C, Eriksson M, Porten M, Herrmann I, Ristimäki A, Virkkunen P, Tarkkanen M, Hakkarainen T, Kanerva A, Rein D, Pesonen S and Hemminki A: Tissue-specific promoters active in $\mathrm{CD} 44^{+} \mathrm{CD} 24^{-/ \text {low }}$ breast cancer cells. Cancer Res 68(14): 5533-5539, 2008. PMID: 18632604. DOI: 10.1158/0008-5472.CAN-07-5288

20 Eriksson M, Guse K, Bauerschmitz G, Virkkunen P, Tarkkanen M, Tanner M, Hakkarainen T, Kanerva A, Desmond RA, Pesonen S and Hemminki A: Oncolytic adenoviruses kill breast cancer initiating CD44+ CD24-/low cells. Mol Ther 15(12): 20882093, 2007. PMID: 17848962. DOI: 10.1038/sj.mt.6300300

21 Jiang H, Gomez-Manzano C, Aoki H, Alonso MM, Kondo S, McCormick F, Xu J, Kondo Y, Bekele BN, Colman H, Lang FF and Fueyo J: Examination of the therapeutic potential of Delta24-RGD in brain tumor stem cells: Role of autophagic cell death. J Natl Cancer Inst 99(18): 1410-1414, 2007. PMID: 17848677. DOI: $10.1093 /$ jnci/djm102

22 Zhang X, Meng S, Zhang R, Ma B, Liu T, Yang Y, Xie W, Liu X, Huang F, Liu T, Zhou X, Liu X and Wang Y: GP73-regulated oncolytic adenoviruses possess potent killing effect on human liver cancer stem-like cells. Oncotarget 7(20): 29346-29358, 2016. PMID: 27121064. DOI: 10.18632/oncotarget.8830

23 Abbink P, Lemckert AAC, Ewald BA, Lynch DM, Denholtz M, Smits S, Holterman L, Damen I, Vogels R, Thorner AR, O'Brien KL, Carville A, Mansfield KG, Goudsmit J, Havenga MJE and Barouch DH: Comparative seroprevalence and immunogenicity of six rare serotype recombinant adenovirus vaccine vectors from subgroups B and D. J Virol 81(9): 4654-4663, 2007. PMID: 17329340 . DOI: $10.1128 /$ JVI.02696-06

24 Khare R, May SM, Vetrini F, Weaver EA, Palmer D, Rosewell A, Grove N, Ng P and Barry MA: Generation of a kupffer cellevading adenovirus for systemic and liver-directed gene transfer. Mol Ther 19(7): 1254-1262, 2011. PMID: 21505422. DOI: $10.1038 / \mathrm{mt} .2011 .71$. 
25 Weaver EA, Hillestad ML, Khare R, Palmer D, Ng P and Barry MA: Characterization of species $\mathrm{C}$ human adenovirus serotype 6 (Ad6). Virology 412(1): 19-27, 2011. PMID: 21251688. DOI: 10.1016/j.virol.2010.10.041

26 Senac JS, Doronin K, Russell SJ, Jelinek DF, Greipp PR and Barry MA: Infection and killing of multiple myeloma by adenoviruses. Hum Gene Ther 21(2): 179-190, 2009. PMID: 19788385. DOI: 10.1089 /hum.2009.082

27 Zhang Z, Zhang X, Newman $K$ and Liu X: MicroRNA regulation of oncolytic adenovirus 6 for selective treatment of castration-resistant prostate cancer. Mol Cancer Ther 11(11): 2410-2418, 2012. PMID: 22914437. DOI: 10.1158/15357163.MCT-12-0157

28 Chen CY, Weaver EA, Khare R, May M and Barry MA: Mining the adenovirus virome for oncolytics against multiple solid tumor types. Immunology 18(10): 744-750, 2011. PMID: 21886190. DOI: $10.1038 /$ cgt.2011.47

29 Shashkova EV, May SM and Barry MA: Characterization of human adenovirus serotypes 5, 6, 11, and 35 as anticancer agents. Virology 394(2): 311-320, 2009. PMID: 19765790. DOI: 10.1016/j.virol.2009.08.038

30 Dolgova EV, Efremov YR, Orishchenko KE, Andrushkevich OM, Alyamkina EA, Proskurina AS, Bayborodin SI, Nikolin VP, Popova NA, Chernykh ER, Ostanin AA, Taranov OS Omigov VV, Minkevich AM, Rogachev VA, Bogachev SS and Shurdov MA: Delivery and processing of exogenous doublestranded DNA in mouse $\mathrm{CD}^{3} 4^{+}$hematopoietic progenitor cells and their cell cycle changes upon combined treatment with cyclophosphamide and double-stranded DNA. Gene 528(2): 74-83, 2013. PMID: 23911305. DOI: 10.1016/j.gene. 2013.06.058

31 Dolgova EV, Alyamkina EA, Efremov YR, Nikolin VP, Popova NA, Tyrinova T V., Kozel AV, Minkevich AM, Andrushkevich OM, Zavyalov EL, Romaschenko AV, Bayborodin SI, Taranov OS, Omigov VV, Shevela EY, Stupak VV, Mishinov SV, Rogachev VA, Proskurina AS, Mayorov VI, Shurdov MA, Ostanin AA, Chernykh ER and Bogachev SS: Identification of cancer stem cells and a strategy for their elimination. Cancer Biol Ther 15(10): 1378-1394, 2014. PMID: 25117082. DOI: $10.4161 / \mathrm{cbt} .29854$

32 Potter EA, Dolgova EV, Proskurina AS, Minkevich AM, Efremov YR, Taranov OS, Omigov VV, Nikolin VP, Popova NA, Bayborodin SI, Ostanin AA, Chernykh ER, Kolchanov NA, Shurdov MA and Bogachev SS: A strategy to eradicate welldeveloped Krebs-2 ascites in mice. Oncotarget 7(10): 1158011594, 2016. PMID: 26872383. DOI: 10.18632/oncotarget.7311

33 Potter EA, Dolgova EV, Proskurina AS, Efremov YR, Minkevich AM, Rozanov AS, Peltek SE, Nikolin VP, Popova NA, Seledtsov IA, Molodtsov VV, Zavyalov EL, Taranov OS, Baiborodin SI, Ostanin AA, Chernykh ER, Kolchanov NA and Bogachev SS: Gene expression profiling of tumor-initiating stem cells from mouse Krebs-2 carcinoma using a novel marker of poorly differentiated cells. Oncotarget 8(6): 9425-9441, 2017. PMID: 28031533. DOI: 10.18632 /oncotarget.14116

34 Dolgova EV, Mishinov SV, Proskurina AS, Potter EA, Efremov YR, Bayborodin SI, Tyrinova TV, Stupak VV, Ostatin AA, Chernykh ER and Bogachev SS: Novel cancer stem marker and its applicability for grading primary human gliomas. Technol Cancer Res Treat 17: 153303461775381, 2018. PMID: 29375020. DOI: $10.1177 / 1533034617753812$
35 Faustino-Rocha A, Oliveira PA, Pinho-Oliveira J, TeixeiraGuedes C, Soares-Maia R, da Costa RG, Colaço B, Pires MJ, Colaço J, Ferreira R and Ginja M: Estimation of rat mammary tumor volume using caliper and ultrasonography measurements. Lab Animal 42: 217-224, 2013. PMID: 23689461. DOI: 10.1038/laban.254

36 Miyai M, Tomita H, Soeda A, Yano H, Iwama T and Hara A: Current trends in mouse models of glioblastoma. J Neurooncol 135(3): 423-432, 2017. PMID: 29052807. DOI: 10.1007/s11060017-2626-2

37 Li X, Wang P, Li H, Du X, Liu M, Huang Q, Wang Y and Wang $\mathrm{S}$ : The efficacy of oncolytic adenovirus is mediated by T-cell responses against virus and tumor in Syrian hamster model. Clin Cancer Res 23(1): 239-249, 2017. PMID: 27435398. DOI: 10.1158/1078-0432.CCR-16-0477

38 Hemminki O, Immonen R, Närväinen J, Kipar A, Paasonen J, Jokivarsi KT, Yli-Ollila H, Soininen P, Partanen K, Joensuu T, Parvianen S, Pesonen SK, Koski A, Vähä-Koskela M, Cerullo $\mathrm{V}$, Pesonen S, Gröhn $\mathrm{OH}$ and Hemminki A: In vivo magnetic resonance imaging and spectroscopy identifies oncolytic adenovirus responders. Int J Cancer 134(12): 2878-2890, 2014. PMID: 24248808. DOI: $10.1002 / \mathrm{ijc} .28615$

39 Eissa IR, Bustos-Villalobos I, Ichinose T, Matsumura S, Naoe Y, Miyajima N, Morimoto D, Mukoyama N, Zhiwen W, Tanaka M, Hasegawa H, Sumigama S, Aleksic B, Kodera Y and Kasuya H: The current status and future prospects of oncolytic viruses in clinical trials against melanoma, glioma, pancreatic, and breast cancers. Cancers (Basel) 10(10): E356, 2018. PMID: 30261620. DOI: $10.3390 /$ cancers 10100356

40 Capone S, Meola A, Ercole BB, Vitelli A, Pezzanera M, Ruggeri L, Davies ME, Tafi R, Santini C, Luzzago A, Fu T-M, Bett A, Colloca S, Cortese R, Nicosia A and Folgori A: A novel adenovirus type 6 (Ad6)-based hepatitis $C$ virus vector that overcomes preexisting anti-Ad5 immunity and induces potent and broad cellular immune responses in rhesus macaques. J Virol 80(4): 1688-1699, 2006. PMID: 16439526. DOI: 10.1128/ JVI.80.4.1688-1699.2006.

41 Alemany R, Suzuki K and Curiel DT: Blood clearance rates of adenovirus type 5 in mice. J Gen Virol 81: 2605-2609, 2000. PMID: 11038370. DOI: 10.1099/0022-1317-81-11-2605

42 Nguyen TV, Heller GJ, Barry ME, Crosby CM, Turner MA and Barry MA: Evaluation of polymer shielding for adenovirus serotype 6 (Ad6) for systemic virotherapy against human prostate cancers. Mol Ther Oncolytics 3: 15021, 2016. PMID: 26900598. DOI: $10.1038 / \mathrm{mto} .2015 .21$

43 Lee SY, Ju MK, Jeon HM, Jeong EK, Lee YJ, Kim CH, Park HP, Han SI and Kang HS: Regulation of tumor progression by programmed necrosis. Oxid Med Cell Longev 2018: 3537471 , 2018. PMID: 29636841. DOI: $10.1155 / 2018 / 3537471$

44 Doronin K, Toth K, Kuppuswamy M, Krajcsi P, Tollefson AE and Wold WS: Overexpression of the ADP (E3-11.6K) protein increases cell lysis and spread of adenovirus. Virology 305(2): 378-387, 2003. PMID: 12573583. DOI: 10.1006/viro.2002.1772

45 Jiang H, White EJ, Rios-Vicil CI, Xu J, Gomez-Manzano C and Fueyo J: Human adenovirus type 5 induces cell lysis through autophagy and autophagy-triggered caspase activity. J Virol 85(10): 4720-4729, 2011. PMID: 21367888. DOI: 10.1128/ JVI.02032-10

46 Tazawa H, Kuroda S, Hasei J, Kagawa S and Fujiwara T: Impact of autophagy in oncolytic adenoviral therapy for cancer. Int $\mathrm{J}$ 
Mol Sci 18(7): E1479, 2017. PMID: 28698504. DOI: 10.3390/ ijms18071479

47 Amaravadi RK and Thompson CB: The roles of therapy-induced autophagy and necrosis in cancer treatment. Clin Cancer Res 13(24): 7271-7279, 2007. PMID: 18094407. DOI: 10.1158/ 1078-0432.CCR-07-1595

48 Silva MT: Secondary necrosis: The natural outcome of the complete apoptotic program. FEBS Lett 584(22): 4491-4499, 2010. PMID: 20974143. DOI: 10.1016/j.febslet.2010.10.046

49 Dean M, Fojo $\mathrm{T}$ and Bates S: Tumour stem cells and drug resistance. Nat Rev Cancer 5(4): 275-284, 2005. PMID: 15803154. DOI: $10.1038 / \mathrm{nrc} 1590$

50 Jackson M, Hassiotou F and Nowak A: Glioblastoma stem-like cells: At the root of tumor recurrence and a therapeutic target. Carcinogenesis 36(2): 177-185, 2014. PMID: 25504149. DOI: $10.1093 /$ carcin/bgu243

51 Yano S, Tazawa H, Hashimoto Y, Shirakawa Y, Kuroda S, Nishizaki M, Kishimoto H, Uno F, Nagasaka T, Urata Y, Kagawa S, Hoffman RM and Fujiwara T: A genetically engineered oncolytic adenovirus decoys and lethally traps quiescent cancer stem-like cells in $\mathrm{S} / \mathrm{G}_{2} / \mathrm{M}$ phases. Clin Cancer Res 19(23): 6495-6505, 2013. PMID: 24081978. DOI: 10.1158/1078-0432.CCR-13-0742
52 Jiang H, Gomez-Manzano C, Aoki H, Alonso MM, Kondo S, McCormick F, Xu J, Kondo Y, Bekele BN, Colman H, Lang FF and Fueyo J: Examination of the therapeutic potential of Delta24-RGD in brain tumor stem cells: Role of autophagic cell death. J Natl Cancer Inst 99(18): 1410-1414, 2007. PMID: 17848677. DOI: $10.1093 /$ jnci/djm102

53 Dolgova EV, Proskurina AS, Potter EA, Tyrinova TV, Taranov OS, Efremov YR, Orishchenko KE, Mishinov SV, Stupak VV, Ostanin AA, Chernykh ER and Bogachev SS: Evaluation of a strategy for tumor-initiating stem cell eradication in primary human glioblastoma cultures as a model. Vavilov J Genet Breed 22(7): 825-836, 2018. DOI: 10.18699/VJ18.31-o

Received July 9, 2019

Revised September 17, 2019

Accepted September 19, 2019 